\title{
Syzygium Cumini Leaves Extract from West Sumatra Indonesia Alleviate Oxidative Stress by Decreasing Malondialdehyde Level and Enhancing Catalase Activity in Rat Induced by Lead Acetate
}

\author{
Rauza Sukma Rita ${ }^{1, *}$, Elmatris Sy ${ }^{2}$ \\ Rauza Sukma Rita ${ }^{1, *}$, Elmatris Sy ${ }^{2}$ \\ 'Department of Biochemistry, Faculty of \\ Medicine, Universitas Andalas, Padang, \\ INDONESIA. \\ ${ }^{2}$ Department of Chemistry, Faculty of \\ Medicine, Universitas Andalas, Padang, \\ INDONESIA.

\begin{abstract}
Introduction: Lead is one of the most dangerous heavy metals in the environment. Contaminated drinking water, battery manufacturing, lead paints, and industrial pollutants are all sources of lead exposure. Lead exposure can cause oxidative stress and is related to many health problems. To prevent oxidative stress caused by lead, the body needs additional antioxidants from the outside body. Syzygium cumini leaf is abundant in antioxidants, which help to minimize oxidative stress caused by lead. Methods: The rats were divided into three groups: negative control, positive control (lead acetate $40 \mathrm{mg} / \mathrm{kg} \mathrm{BW}, 30$ days), and treatment (lead acetate $40 \mathrm{mg} / \mathrm{kg}$ BW and Syzygium cumini leaves extract $150 \mathrm{mg} / \mathrm{kg} \mathrm{BW}, 30$ days). At the end of the experiment, blood was collected and prepared to measure malondialdehyde and catalase activity. Results: The leaf extract of Syzygium cumini reduced serum malondialdehyde levels while increasing catalase activity. Conclusion: Lead exposure induces oxidative stress, which can be reduced by Syzygium cumini's leaves.

Key words: Lead acetate, Syzygium cumini's leaves, Malondialdehyde, Catalase activity, Rat.
\end{abstract}

\section{Correspondence}

Rauza Sukma Rita

Department of Biochemistry, Faculty of Medicine, Universitas Andalas, Padang, INDONESIA.

E-mail: rauzasukmarita@med.unand.ac.id

History

- Submission Date: 19-06-2021;

- Review completed: 19-07-2021;

- Accepted Date: 30-07-2021.

DOI : 10.5530/pj.2021.13.178

Article Available online

http://www.phcogj.com/v13/i6

Copyright

(C) 2021 Phcogj.Com. This is an openaccess article distributed under the terms of the Creative Commons Attribution 4.0 International license.

\section{INTRODUCTION}

Free radicals are molecules that contain unpaired electrons in a set of atoms. ${ }^{1-3}$ Excessive amounts of free radicals can cause damage to cells, DNA, and proteins. The long-term impact of free radicals is also associated with degenerative diseases, such as diabetes mellitus, coronary heart disease, etc. ${ }^{4-6}$ The source of free radicals can come from inside the body and from outside the body. ${ }^{5,7}$ One of the sources of free radicals from outside the body comes from heavy metal pollution, such as Cadmium, Chromium, Copper, Mercury, Lead, and Zinc. ${ }^{8-11}$ Among these elements, lead is a heavy metal that is the most essential toxic in the environment. ${ }^{12,13}$

Lead $(\mathrm{Pb})$ is a persistent non-essential metal that is colorless, odorless, and tasteless. ${ }^{14}$ Lead tends to catalyze oxidation reactions and lead to the formation of reactive oxygen species or ROS.,15 Reactive oxygen species (ROS) cause substantial damage to biological molecules such as DNA, enzymes, and proteins. ${ }^{16}$ These reactive oxygen species (ROS) can also cause cell membrane lipid peroxidation. ${ }^{17-19}$ Lead is absorbed, conjugated in the liver, and transported to the kidneys, where small quantities are eliminated through urine; nevertheless, most lead accumulates in numerous organs. ${ }^{14}$

Endogenous antioxidants are insufficient to counteract oxidative stress in the body induced by lead acetate poisoning. As a consequence, antioxidants from the outer body are also required. One plant that is rich in antioxidants is Jamun or Syzygium cumini. It is an important indigenous plant from Indonesia and India ${ }^{20}$ which belongs to the Myrtaceae family. ${ }^{20,21}$ Syzygium cumini has been reported to have effects in overcoming diseases, such as antibacterial, antimicrobial, antiHIV, anti-diarrhea, anti-inflammatory, antifungal, gastroprotective and anti-ulcerogenic, anorexigenic, and others. ${ }^{22,23}$

Various parts of Syzygium cumini, namely root, stem, leaves, flower, fruit pulp, and seed, have been used for medicinal purposes. Among the components of Syzygium cumini, the leaves are known to contain many active phytochemical compounds such as crategolic acid, mycaminose, betulinic acid, ß-sitosterol, n-nonacosane, n-hepatcosane, $\mathrm{n}$-hentriacontane, n-dotricontanol, n-triacontanol, noctacosanol, myricetin, quercetin, octacosane, octadecane, eicosane, tannins, triterpenoids, acylated flavonol glycosides, and rhamnopyranosides..$^{22,24,25}$ Most of these compounds are rich in antioxidants that can fight free radicals. Research related to the administration of Syzygium cumini leaf extract in overcoming oxidative stress due to lead exposure in West Sumatra, Indonesia, is still limited. Therefore, this study aims to analyze the effect of Syzygium cumini leaf extract on endogenous lipid peroxidation and antioxidant parameters due to lead exposure.

\section{MATERIALS AND METHODS}

\section{Animals}

This research was conducted on male Wistar rats (Rattus norvegicus). Before the study, rats were acclimatized for one week and given free access to food and drink. A total of 18 white male rats Wistar strain (Rattus norvegicus) were divided into three groups, namely the negative control group (normal saline), positive control (lead acetate $40 \mathrm{mg} / \mathrm{kg} \mathrm{BW}$ for 30 days), and treatment (lead acetate $40 \mathrm{mg} / \mathrm{kg}$ BW and Syzygium cumini' extracts $150 \mathrm{mg} / \mathrm{kg} \mathrm{BW}$ for 30 days). After passing the ethical test performed

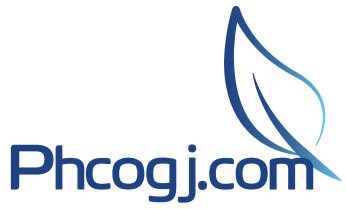

Cite this article: Rita RS, Sy E. Syzygium Cumini Leaves Extract from West Sumatra Indonesia Alleviate Oxidative Stress by Decreasing Malondialdehyde Level and Enhancing Catalase Activity in Rat Induced by Lead Acetate. Pharmacogn J. 2021;13(6): 1408-1412. 
by the Ethics Commission of the Faculty of Medicine, Universitas Andalas, No. 113/UN.16.2/KEP-FK/2020, this study was carried out.

\section{Chemicals and Reagents}

Tricarboxylic Acid and Thiobarbituric Acid were utilized to quantify Malondialdehyde serum using the Thiobarbituric acid reactive substance (TBARS) test. Catalase activity was measured using colorimetry methods utilizing potassium dichromate, acetic acid, and hydrogen peroxide. Lead acetate and all of the ingredients were provided by Sigma Aldrich in Germany.

\section{Preparation of Syzygium cumini's leaves extracts}

Syzygium cumini leaves were obtained from West Sumatra Province, Indonesia, and confirmed from the Herbarium of Universitas Andalas, Padang, West Sumatra, Indonesia, No. 320/K-ID/ANDA/X/20. Syzygium cumini leaf extract was made at the Pharmacology Laboratory, Faculty of Pharmacy, Universitas Andalas. The leaves of Syzygium cumini, which are still fresh, weighing $2.5 \mathrm{~kg}$, are cleaned and washed using running water, then cut into small pieces, and then dried by aerating in the open-air protected from sunlight. After drying, the leaves of Syzygium cumini are ground to form a coarse powder.

The extract of Syzygium cumini leaves used the maceration method with a $96 \%$ ethanol mixture. The maceration method is carried out for three days in a dark container protected from direct sunlight, then stirring regularly. The maceration process was carried out in the next three days to extract the entire extract. The collected macerate will be evaporated by vacuum distillation and then filtered using a tool called a rotary evaporator at a temperature of $40^{\circ} \mathrm{C}$ to then produce a pure extract of Syzygium cumini leaves with a thick texture.

\section{Measurement of Malondyadehide}

Rat serum $(500 \mu \mathrm{l})$ is added with $2.5 \mathrm{ml}$ of TCA $5 \%$, then mixed with a vortex mixer. Once mixed, centrifuge for 10 minutes at a speed of 2000 RPM. The centrifuge is repeated for 10 minutes, the same treatment on standard and blank solutions. According to the label, each tube is taken $1.5 \mathrm{ml}$ filtrat using a pipette, then inserted into the tube. Furthermore, on each tube added $1.5 \mathrm{ml} \mathrm{Na}$ Thio Barbituric Acid, mixed using a vortex mixer. After that, it is heated in the water bath for 30 minutes, then cooled and ready to read using Spectrophotometer (Spectronic 20) at $\lambda 550 \mathrm{~nm}^{26}$

\section{Measurement of Catalase Activity}

In the tube, $4 \mathrm{ml} \mathrm{H}_{2} \mathrm{O}_{2}$ (hydrogen peroxide, $0.2 \mathrm{M}$ ) solution was added, followed by $5 \mathrm{ml}$ buffer phosphate. After that, slowly add $1 \mathrm{~mL}$ of serum and homogenize. This reaction is measured in milliliters and then added to 2 milliliters of glacial acetate. This procedure is repeated 60 seconds apart on various tubes. To eliminate blue precipitation and produce green precipitation, the tube is heated in boiling water for 10 minutes. At a wavelength of $570 \mathrm{~nm}$, the absorbant is measured. When the process is stopped by acetic acid, the standard curve is used to determine how much $\mathrm{H}_{2} \mathrm{O}_{2}$ remains. The amount of protein consumed is determined by the activity of enzymes. ${ }^{26}$

\section{Statistical Analysis}

The data is presented as a mean s.e.m. One-way ANOVA was used in the statistical analysis, followed by multiple comparison tests. Statistical significance was defined as $\mathrm{p}$ values $<0.05$.

\section{RESULTS}

\section{Effect of Syzygium cumini's extract on malondialdehyde serum levels}

Lead acetate administration (40 mg/kg BW, 30 days) increased malondialdehyde serum level in the rat. This increase is significant

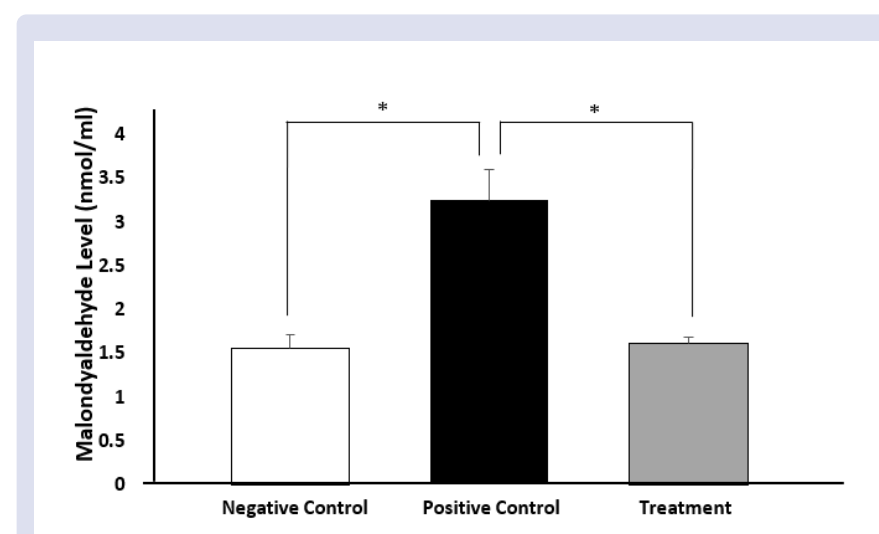

Figure 1: Syzygium cumini's extract decreased malondialdehyde serum levels. Lead acetate increased malondialdehyde serum level compared to negative control group $(3.25 \mathrm{nmol} / \mathrm{ml}$ vs $1.56 \mathrm{nmol} /$ $\mathrm{ml},{ }^{*} p$-value $\left.<0.05\right)$. Administration of Syzygium cumini's extract counteracts $\mathrm{Pb}$ acetate increased malondialdehyde levels (1.62 $\mathrm{nmol} / \mathrm{ml}$ vs $3.25 \mathrm{nmol} / \mathrm{ml}$, * $p$-value $<0.05)$.

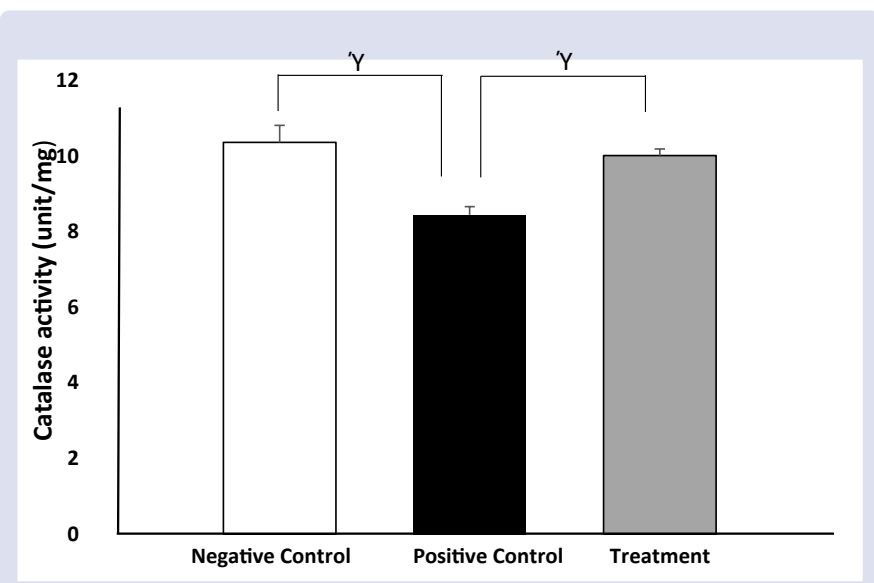

Figure 2: Catalase activity enhanced by Syzygium cumini's extract. Administration of $\mathrm{Pb}$ acetate decreased catalase activity compared to negative control group significantly ( 8.45 unit/mg vs 10.37 unit/ $\mathrm{mg},{ }^{*} p$-value $\left.<0.05\right)$. Syzygium cumini's extract enhanced catalase activity compared to positive control group significantly (10.01 unit/mg vs 8.45 unit/mg, ${ }^{*} p$-value $\left.<0.05\right)$.

compared to the negative control group $(\mathrm{p}<0.05)$. Syzygium cumini's extract $(150 \mathrm{mg} / \mathrm{kg}$ BW, 30 days) counteracts lead acetate-induced malondialdehyde enhancement, and this level no different with a negative control group (Figure 1).

\section{Effect of Syzygium cumini's extract on catalase's activity}

In figure 2, catalase activity decreased by administration of lead acetate (40 mg/kg BW for 30 days), and this was significant compared to either the negative control group and treatment group ( $\mathrm{p}$-value $<0.05)$. The treatment group showed an increase in catalase activity significantly compared to a positive control group ( $\mathrm{p}$-value $<0.05$ )

\section{DISCUSSION}

In this study, the administration of lead acetate $(40 \mathrm{mg} / \mathrm{kg} \mathrm{BW})$ led to increased Malondialdehyde levels and decreased activity of serum catalase in rats. Lead acetate is a heavy metal that is widely found in everyday life. ${ }^{12,27}$ Exposure to lead acetate can increase free radicals in the body. ${ }^{16,28-30}$ Increased free radicals lead to a rise in lipid peroxidation, ${ }^{31-33}$ one of the remaining lipid peroxidations often found 
is Malondialdehyde. ${ }^{17-19}$ Previous research has shown that exposure to lead acetate leads to elevated levels of blood Malondialdehyde. ${ }^{34}$ Furthermore, increased free radicals due to lead acetate also lead to decreased levels of endogenous antioxidant activity, such as catalase, SOD, and Glutathione peroxidase. ${ }^{34,35}$ Antioxidant enzyme activity is lowered because lead has a strong affinity for $\mathrm{SH}$ groups or metal cofactors in antioxidant enzymes and substances. ${ }^{35}$

In rats given lead acetate $(40 \mathrm{mg} / \mathrm{kg} \mathrm{BW})$, administering Syzygium cumini leaf extract $(150 \mathrm{mg} / \mathrm{kg}$ BW) resulted in lower serum malondialdehyde levels and increased catalase activity. Tannins, flavonoids, phenols, triterpenoids, saponins, alkaloids, glycosides, steroids, fatty acids, proteins, and other substances are found in Syzygium cumini leaf extract..$^{20}$ Phenol and flanovoid components are reported to have high antioxidant activity. ${ }^{20,36}$ According to another study, Syzygium cumini leaf extract contains quercetin, myricetin, kaempferol, and glycosides. ${ }^{37}$ Because of the high antioxidant content of Syzygium cumini leaf extract, Malondialdehyde levels are reduced, and catalase activity was raised, thus diminishing oxidative stress. Reactive oxygen species can be neutralized by exogenous antioxidants acquired from medicinal plants. ${ }^{37}$

\section{CONCLUSION}

Lead acetate exposure can raise free radical levels in the body, causing oxidative stress. Because of its potent antioxidant content, this study reveals that Syzygium cumini leaf extract has the potential to overcome oxidative stress caused by lead exposure.

\section{CONFLICTS OF INTEREST}

The authors declare no conflicts of interest.

\section{ACKNOWLEDGEMENT}

Research financially supported this study by Grant Fundamental Scheme No.23/UN.16.02/Fd/PT.01.03/2020 from the Faculty of Medicine, Universitas Andalas, Padang, Indonesia.

\section{REFERENCES}

1. Phaniendra A, Jestadi DB, Periyasamy L. Free Radicals: Properties, Sources, Targets, and Their Implication in Various Diseases. Indian J Clin Biochem. 2015;30(1):11-26. doi:10.1007/s12291-014-0446-0

2. Alisi IO, Uzairu A, Abechi SE. Molecular design of curcumin analogues with potent antioxidant properties and thermodynamic evaluation of their mechanism of free radical scavenge. Bull Natl Res Cent. 2020;44(1). doi:10.1186/s42269-020-00391-z

3. Yang $W$, Zhang $L$, Xiao $D$, et al. A diradical based on odd-electron o-bonds. Nat Commun. 2020;11(1):1-8. doi:10.1038/s41467-020 17303-4

4. Sharifi-Rad M, Anil Kumar N V., Zucca P, et al. Lifestyle, Oxidative Stress, and Antioxidants: Back and Forth in the Pathophysiology of Chronic Diseases. Front Physiol. 2020;11(July):1-21. doi:10.3389/ fphys.2020.00694

5. Lobo V, Patil A, Phatak A, Chandra N. Free radicals, antioxidants and functional foods: Impact on human health. Pharmacogn Rev. 2010:4(8):118-126. doi:10.4103/0973-7847.70902

6. Katerji M, Filippova M, Duerksen-Hughes P. Approaches and methods to measure oxidative stress in clinical samples: Research applications in the cancer field. Oxid Med Cell Longev. 2019;2019:1 29. doi:10.1155/2019/1279250

7. Di Meo S, Venditti P. Evolution of the Knowledge of Free Radicals and Other Oxidants. Oxid Med Cell Longev. 2020;2020:1-32. doi:10.1155/2020/9829176

8. Ali H, Khan E, Ilahi I. Environmental chemistry and ecotoxicology of hazardous heavy metals: Environmental persistence, toxicity, and bioaccumulation. J Chem. 2019;2019:1-14. doi:10.1155/2019/6730305
9. Obasi PN, Akudinobi BB. Potential health risk and levels of heavy metals in water resources of lead-zinc mining communities of Abakaliki, southeast Nigeria. App/ Water Sci. 2020;10(7):1-23. doi:10.1007/s13201-020-01233-z

10. Tchounwou PB, Yedjou CG, Patlolla AK, Sutton DJ. Molecular clinical and environmental toxicicology Volume 3: Environmenta Toxicology. Mol Clin Environ Toxicol. 2012:101:133-164. doi:10.1007/978-3-7643-8340-4

11. Jaishankar M, Tseten T, Anbalagan N, Mathew BB, Beeregowda $\mathrm{KN}$. Toxicity, mechanism and health effects of some heavy metals Interdiscip Toxicol. 2014;7(2):60-72. doi:10.2478/intox-2014-0009

12. Wani AL, Ara A, Usmani JA. Lead toxicity: A review. Interdiscip Toxicol. 2015;8(2):55-64. doi:10.1515/intox-2015-0009

13. Tiwari S, Tripathi IP, Gandhi M, Gramoday C, Tiwari H. Effects of Lead on Environment. Int J Emerg Res Manag Technol. 2013;2(6). doi:10.11468/seikatsueisei1957.28.190

14. Al-Megrin WA, Alkhuriji AF, Yousef AOS, et al. Antagonistic efficacy of luteolin against lead acetate exposure-associated with hepatotoxicity is mediated via antioxidant, anti-inflammatory, and anti-apoptotic activities. Antioxidants. 2020;9(1). doi:10.3390/ antiox9010010

15. Pizzino G, Irrera N, Cucinotta M, et al. Oxidative Stress: Harms and Benefits for Human Health. Oxid Med Cell Longev. 2017;2017:1 13. doi:10.1155/2017/8416763

16. Abd Elrasoul A, Mousa A, Orabi S, Gadallah S, Abd eldaim mabrouk Ameliorative Effect of Azolla Pinnata Ethanolic Extract on RanitidineInduced Hepatotoxicity in Rats. J Curr Vet Res. 2020;2(2):87-95. doi:10.21608/jcvr.2020.121532

17. Mendonça R, Gning O, Di Cesaré $\mathrm{C}$, et al. Sensitive and selective quantifcation of free and total malondialdehyde in plasma using UHPLC-HRMS. J Lipid Res. 2017;58(9):1924-1931. doi:10.1194/jlr. D076661

18. Bergin $P$, Leggett $A$, Cardwell $C R$, et al. The effects of vitamin $E$ supplementation on malondialdehyde as a biomarker of oxidative stress in haemodialysis patients: a systematic review and metaanalysis. BMC Nephrol. 2021;22(1):1-10. doi:10.1186/s12882-02102328-8

19. Djordjević A Kotnik $\mathrm{P}$ Horvat $\mathrm{D}$, Knez Ž Antonič $M$ Pharmacodynamics of malondialdehyde as indirect oxidative stress marker after arrested-heart cardiopulmonary bypass surgery. Biomed Pharmacother. 2020;132(August):1-5. doi:10.1016/j. biopha.2020.110877

20. Dwivedi N, Trivedi K, Tripathi IP. Antihyperglycemic Activity Free Radical Scavenging Activity and FTIR of Syzygium Cumin Linn Pulp Dried Extract. J Vaccines Vaccin. 2020;11(420):11-13. doi:10.35248/2157-7560.20.11.420

21. Balyan U, Sarkar B. Aqueous extraction kinetics of phenolic compounds from jamun (Syzygium cumini L.) seeds. Int J Food Prop. 2017;20(2):372-389. doi:10.1080/10942912.2016.1163266

22. Agarwal P, Gaur PK, Tyagi N, Puri D, Kumar N, Kumar SS. An Overview of Phytochemical, Therapeutic, Pharmacological and Traditional Importance of Syzygium cumini . Asian J Pharmacogn. 2019;3(1):5-17

23. Haque R, Sumiya MK, Sakib N, et al. Antimicrobial Activity of Jambul (\&lt;i\&gt:Syzygium cumini\&lt;/i\&gt;) Fruit Extract on Enteric Pathogenic Bacteria. Adv Microbiol. 2017;07(03):195-204. doi:10.4236/aim.2017.73016

24. Ramya S, Neethirajan K, Jayakumararaj R. Profile of bioactive compounds in Syzygium cumini-a review. Artic J Pharm Res. 2013;(March 2013).

25. Jagetia GC. Phytochemical Composition and Pleotropic Pharmacological Properties of Jamun, Syzygium Cumin Skeels. J Explor Res Pharmacol. 2017;2(2):54-66. doi:10.14218/ jerp.2016.00038 
26. Rita RS, Yerizel E, Asbiran N, Kadri H. Pengaruh Ekstrak Mengkudu terhadap Kadar Malonaldehid darah dan aktivitas katalase Tikus DM yang diinduksi Aloksan. Maj Kedokt Andalas. 2009;33(1):54-64.

27. Kim HJ, Mahboob S, Viayaraghavan P, et al. Determination of toxic effects of lead acetate on different sizes of zebra fish (Danio rerio) in soft and hard water. J King Saud Univ - Sci. 2020;32(2):13901394. doi:10.1016/j.jksus.2019.11.032

28. Obafemi TO, Onasanya A, Adeoye A, et al. Protective effect of methanolic and flavonoid-rich leaf extracts of Synsepalum dulcificum (Danielli) on lead-acetate-induced toxicity in Wistar albino rats. J Appl Pharm Sci. 2019;9(5):65-72. doi:10.7324/JAPS.2019.90508

29. Al-Attar AM. Therapeutic influences of almond oil on male rats exposed to a sublethal concentration of lead. Saudi J Biol Sci. 2020;27(2):581-587. doi:10.1016/j.sjbs.2019.12.035

30. Kumar Singh $P$, Kumar Singh $M$, Singh Yadav $R$, Kumar Dixit $R$, Mehrotra A, Nath R. Attenuation of Lead-Induced Neurotoxicity by Omega-3 Fatty Acid in Rats. Ann Neurosci. 2018;24(4):221-232. doi:10.1159/000481808

31. Alché $\mathrm{J}$ de $\mathrm{D}$. A concise appraisal of lipid oxidation and lipoxidation in higher plants. Redox Biol. 2019;23(January):101136. doi:10.1016/j. redox.2019.101136
32. Taso O V., Philippou A, Moustogiannis A, Zevolis E, Koutsilieris M. Lipid peroxidation products and their role in neurodegenerative diseases. Ann Res Hosp. 2019;3(4):2-2. doi:10.21037/ arh.2018.12.02

33. Gao J, Hu J, Hu D, Yang X. A Role of Gallic Acid in Oxidative Damage Diseases: A Comprehensive Review. Nat Prod Commun 2019:14(8). doi:10.1177/1934578X19874174

34. Andjelkovic M, Djordjevic AB, Antonijevic E, et al. Toxic effect of acute cadmium and lead exposure in rat blood, liver, and kidney. Int J Environ Res Public Health. 2019;16(2). doi:10.3390/ijerph16020274

35. Wang J, Zhu H, Yang Z LZ. Antioxidative effects of hesperetin against lead acetate-induced oxidative stress in rats. Indian $J$ Pharmacol. 2013;45(4):395-398

36. Ahmed R, Tariq M, Hussain M, et al. Phenolic contents-based assessment of therapeutic potential of Syzygium cumini leaves extract. PLoS One. 2019;14(8):1-16. doi:10.1371/journal. pone.0221318

37. Chagas VT, De Sousa Coelho RMR, Gaspar RS, et al. Protective effects of a polyphenol-rich extract from syzygium cumini (L.) skeels leaf on oxidative stress-induced diabetic rats. Oxid Med Cell Longev. 2019;2018:1-13. doi:10.1155/2019/5785798

\section{GRAPHICAL ABSTRACT}

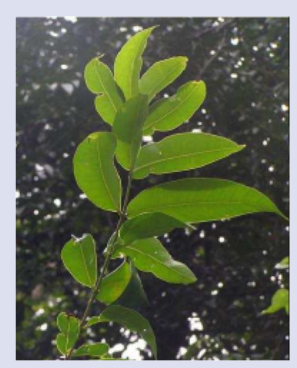

Syzygium cumini's leaves

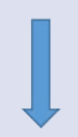

Extraction process

\section{Lead Acetate}
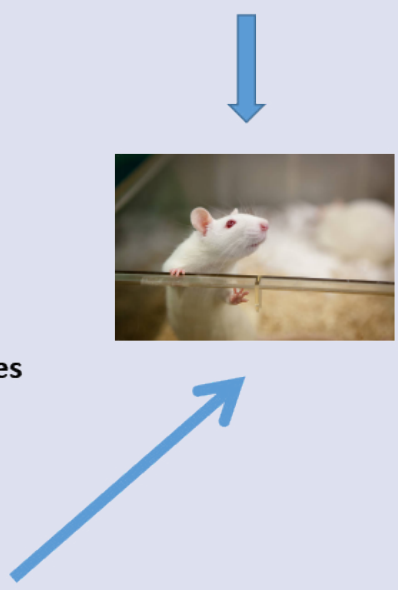

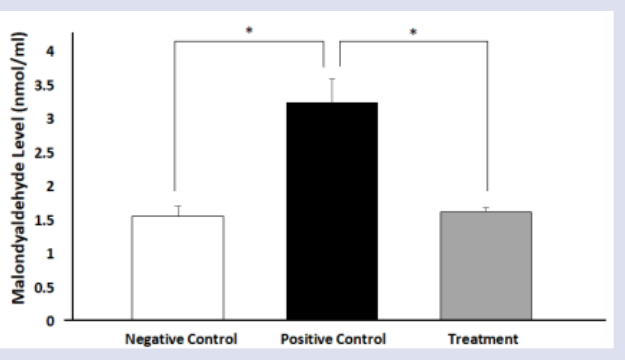

Syzygium cumini's leaves extracts alleviate oxidative stress 


\section{ABOUT AUTHORS}

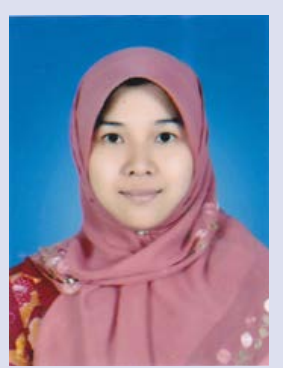

Rauza Sukma Rita is a lecturer at the Department of Biochemistry, Faculty of Medicine, Universitas Andalas, Padang, Indonesia. She graduated as Medical Doctor from the Faculty of Medicine, Universitas Andalas, in 2009. She continued to get Ph.D. Program from Jichi Medical University, Japan, and graduated in 2015. Her research interest is oxidative stress, diabetes mellitus, obesity and other degenerative diseases, and herbal medicine.

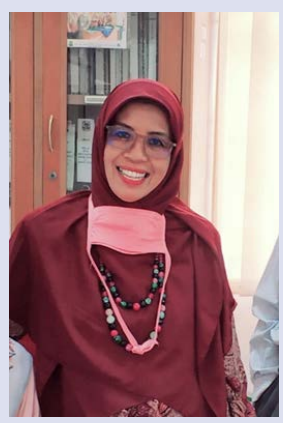

Elmatris Sy is a lecturer at Universitas Andalas, Padang, Indonesia, in the Department of Chemistry, Faculty of Medicine. She graduated Bachelor's Degree in chemistry from the Faculty of Mathematics and Natural Sciences, Universitas Andalas, in 1986. In 1992, she completed a Master's Degree Program in analytical chemistry at Institut Teknologi Bandung. Toxicology, oxidative stress, and its treatment are among her scientific interests.

Cite this article: Rita RS, Sy E. Syzygium Cumini Leaves Extract from West Sumatra Indonesia Alleviate Oxidative Stress by Decreasing Malondialdehyde Level and Enhancing Catalase Activity in Rat Induced by Lead Acetate. Pharmacogn J. 2021;13(6): 1408-1412. 